\title{
ANTITRUST PROBLEMS IN THE TELEVISION BROADCASTING INDUSTRY
}

\author{
EManued CelleR*
}

I

IN'RODUCTION

During 1955, the Antitrust Subcommittee of the House Judiciary Committee held hearings on current antitrust problems posed by new forces active in the economy. ${ }^{1}$ At those hearings, testimony was presented to the effect that Federal regulatory agencies, including the Federal Communications Commission, not only had become unduly industry-minded, but had, contrary to antitrust principles, sanctioned excessive concentration in the industries subject to their jurisdiction. ${ }^{2}$ This testimony was particularly disquieting in its bearing on television broadcasting, where antitrust objectives assume great significance.

The subcommittee, accordingly, instituted a thorough preliminary investigation into various aspects of television broadcasting and into the manner in which the Federal Communications Commission and the Department of Justice had exercised their responsibilities in this vital new branch of mass communications. Thereafter, at public hearings, ${ }^{3}$ the subcommittee received testimony from witnesses representing many different points of view, including members of the Federal Communications Commission, the former and present heads of the Antitrust Division of the Department of Justice, the president of each of the television networks, officials of independent television film producing companies, station licensees, advertisers, representatives of music licensing organizations, songwriters, and other persons familiar with different phases of the industry.

This article embodies the writer's views concerning the salient antitrust problems encountered in the television broadcasting industry and remedies proposed for their solution. ${ }^{4}$

\section{A. Unique Character of Television}

Certain characteristics of television broadcasting distinguish it from other mass communications media, such as motion pictures and the press and even, to some extent, radio, and create need both for a degree of government regulation and for vigorous antitrust enforcement.

A.B. 19ro, LL.B. 1912, Columbia University. Member of Congress from New York; Chairman of the House Judiciary Committee and of its Antitrust Subcommittee.

${ }^{1}$ Hearings before the Antitrust Subcommittee of the House Committee on the Judiciary on Current Antitrust Problems, 84th Cong., ist Sess. (1955).

sec, e.g., id. at 289-90, 308(a), (b). For a recent assertion of this general thesis, see Walton Hamilton, The Politics of Industry 51-62 (1957).

${ }^{3}$ Hearings before the Antitrust Subcommittee of the House Committee on the Judiciary on Monopoly Problems in Regulated Industries, 84th Cong., 2d Sess., ser. 22, pt. 2, vol. I-4, at 3107-6448 (1956).

'Sec also House Committee on the Judiciary, Report of the Antitrust Subcommittee on the Television Broadcasting Industry, H. REP. No. 607, 85th Cong., Ist Sess. (1957). 
Television exploits the radio spectrum, a precious natural resource which belongs to all the people and is finite in extent. In the present state of technology, the spectrum affords only a limited, perhaps an inadequate, number of frequencies suitable for audiovisual broadcasting, and stations using identical or adjacent channels must be minimally separated to avoid interference. ${ }^{.}$The number of operating television broadcasting stations has never been sufficient to afford a fully nationwide and competitive system. There has been keen competition for the privilege of operating profitable VHF (very high frequency) stations and an ominous growing reluctance to risk investment in the younger technique of UHF (ultra high frequency) broadcasting. ${ }^{6}$ The physical limitations of the medium, thus, make it essential in the public interest that a competent authority shall supervise outlet allocations and select among competing license applicants.

Aspects of the industry's economic organization combine with chronic station shortage to make for concentration of control. Commercial television, like radio, subsists entirely upon advertising revenues. National advertisers, with huge budgets, demand access to a nationwide consumer market. This pressure and the high cost of superior programming render networking essential. Networking brings individual, primarily independently-owned television stations into contractual affiliation with one or more network organizations for the purpose of receiving network programs over a nationwide hookup and simultaneously broadcasting these programs locally. The scarcity of station outlets, however, has been such as to permit the development of only two full-fledged national networks, CBS and NBC, which in consequence enjoy a dominant place in the industry. ${ }^{\text {? }}$

Television networks engage in a number of practices which they deem necessary to assure station clearance for network programs and to assure high quality programming, but which tend to have a restrictive and discriminatory impact. What is more, broadcasters, including the network organizations, have established their own music-licensing agency, through which they compete with and are in a position to discriminate against musical compositions licensed by the association of the songwriters.

Extension of restrictive or discriminatory practices in television broadcasting not only would have grave economic consequences for elements of the industry, but would directly and disastrously affect the entire viewing public. The American people have a vital stake in a television system based on competitive free enterprisea system that enables many communities to produce their own programs and, at the same time, fosters the growth of several competing networks. Monopolistic control

A television channel requires spectrum space of 6 megacycles (6000 kilocycles), as compared to the single megacycle ( 540 to 1600 kilocycles) used by all the AM radio channels.

- Television broadcasting uses two bands of differing frequency ranges. The VHF band is defined to include frequencies ranging from 30 to 300 megacycles; the UHF to include frequencies ranging from 300 to 3000 megacycles.

${ }^{2}$ In 1955, CBS and NBC and their wholly-owned stations together enjoyed over $40 \%$ of the entire industry's broadcast revenues and over $40 \%$ of the entire industry's broadcast income before federal taxes. See tabulation, infra pp. 558-59. 
of television, should it exist, would enable the dominant interest to convert the public airwaves into a medium for force-feeding the public with hand-picked opinions and programs. It would mark the end of hoped-for multiplicity of independent local station outlets devoted to the dissemination of programs of local origin and the encouragement of local talent. And it would negate the fundamental principle that mass communications in a democratic society call for "the widest possible dissemination of information from diverse and antagonistic sources." 8

\section{B. The Statutory Setting}

To provide needed supervision of the use of the airwaves and, at the same time, guard against the possibility of their monopolization, Congress enacted the Communications Act of $19344^{9}$ the basic statute relating to radio and television broadcasting. By this enactment, the Federal Communications Commission is empowered to allocate broadcast frequencies, ${ }^{10}$ and a Commission license is made prerequisite to the construction or operation of a broadcasting station, but no person can become the owner of a channel of communications ${ }^{11}$ and no broadcast license may be granted for a longer term than three years. ${ }^{12}$ Although networks, as such, are not subject to supervision, the Commission has express authority to make regulations applicable to broadcasting stations engaged in chain broadcasting. ${ }^{13}$

In adopting this Act, Congress "moved under the spur of a widespread fear that in the absence of governmental control the public interest might be subordinated to monopolistic domination in the broadcasting field." ${ }^{\text {"14 }}$ But it did not subject broadcasting to detailed control of rates, prices, or finances. Making clear that, subject to the limitations of the spectrum, private enterprise competition remains a primary objective for broadcasting, the Act provides that: ${ }^{15}$

All laws of the United States relating to unlawful restraints and monopolies and to combinations, contracts, or agreements in restraint of trade are hereby declared to be applicable to .... interstate or foreign radio communications.

Responsibility to enforce the antitrust laws, which are thus made expressly applicable to broadcasting, lies primarily with the Attorney General and the Federal Trade Commission, but the Federal Communications Commission also is obligated to administer its regulatory activities in a manner harmonious with the purposes of those laws. In a licensing proceeding, for example, competition is a relevant factor in weighing the public interest. ${ }^{10}$ In furtherance of its antitrust responsibilities,

${ }^{8}$ Associated Press v. United States, 326 U.S. I, 20 (I945).

${ }^{\circ} 8$ STAт. 1064, 47 U.S.C. $\$ \$ 151$ et seq. (1952).

${ }_{10}^{10}$ 50 STAT. r9o (I937), 47 U.S.C. $\$ 303$ (c) and (d) (1952).

1148 STAT. 1081, 47 U.S.C. $\$ 301$ (I952).

1366 STAT. 714, 47 U.S.C. \$ 307 (d) (1952).

${ }^{13} 50$ STAT. I90 (1937), 47 U.S.C. $\$ 303$ (i) (r952).

14 FCC v. Pottsville Broadcasting Co., 309 U.S. 134,137 (1940).

${ }^{10} 48$ STAT. 1087,47 U.S.C. $\$ 313$ (1952). The same section provides that a party found guilty of antitrust violations may in the court's discretion have its station license revoked. Section 31 I (66 STAT. 716) directs the FCC to refuse further license to persons whose license has been revoked.

${ }^{10}$ FCC v. Radio Corporation of America, 346 U.S. 86, 94 (I953). 
the Commission has promulgated chain-broadcasting regulations governing contractual relations between stations and networks and has limited the number of stations one person may own. ${ }^{17}$

\section{Growth and Structure of the Industry}

Television broadcasting was first authorized in $194 \mathrm{r}$, but its development was delayed by wartime dislocations. In 1945, there were only six commercial television broadcast stations in operation. The ensuing decade saw tremendous growth. Today, 455 such stations broadcast their programs to more than 37 million receiving sets. Over 90 per cent of the American people are within receiving distance of at least one station and 75 per cent are in a position to receive the programs of two or more stations.

All but $3^{8}$ of the 455 operating television stations are affiliated with one or more of three television networks. Each network owns and operates a number of stations ${ }^{18}$ in key market areas, but the remainder of the affiliated stations are owned by nonnetwork interests. It is estimated that the average television station devotes about $5^{I}$ per cent of its broadcast time to network programs. ${ }^{10}$ In 1955, the broadcast revenues of the four networks then in operation and their 16 wholly-owned stations exceeded $\$ 374$ million and accounted for 50.23 per cent of total industry revenues from broadcasting.

To bring their message to the viewing audience, advertisers purchase station time or network time and, in addition, pay programming costs. Network time charges are the aggregate of the time charges of each station carrying the program, less certain quantity discounts. Programs are broadcast live or on film. ${ }^{20}$ Both types of programs are produced independently or by networks, and each of the networks has a financial interest of some kind in a substantial portion of the programs broadcast by it. ${ }^{21}$

Despite the availability to individual stations of a variety of programs from nonnetwork sources, a network affiliation contributes immeasurably to the success of a station. In the first place, network pioneering, both financial and technical, has created programs of great public appeal. Second, the broadcast of a commercial network program gives the station a share (approximately $3^{\circ}$ per cent) of the revenue from the network's sale of the station's time and relieves the station of the necessity and expense of developing its own programming. Finally, the broadcast of popular

${ }^{17}$ The Commission has been engaged in a network study to determine whether the present operation of radio and television networks tends to foster or impede development of a nationwide competitive system and to reappraise its chain-broadcasting regulations, which have been in effect for radio since I 943 and for television since 945 . FCC, Network Broadcasting, Report of the Network Study Stapp to the Network Study CoMnitiee (1957).

${ }^{18} \mathrm{CBS}$ owns 5 VHF and 2 UHF stations; NBC, 5 VHF and 2 UHF; and ABC, 5 VHF. Sce tabulation infra pp. 558-59. Commission rules limit a single owner to 7 stations, not more than 5 of which shall be VHF.

${ }^{10}$ House Committee on the Judiciary, supra note 4 , at 22.

${ }^{20}$ About $27 \%$ of all network program time involves film. The percentage is 20 for CBS, I6 for $\mathrm{NBC}$, and 63 for $\mathrm{ABC}$.

${ }^{21}$ See p. 565 infra. 
programs attracts a large viewing audience to the station's channel and thus increases the value to advertisers of the station's non-network time. These factors no doubt account for the fact that the great preponderance of broadcast stations have network affiliations and that a substantial number of the $3^{8}$ nonaffiliated stations have "per program" network arrangements.

Although television broadcasting has achieved spectacular growth, two major obstacles have to date retarded the full realization of competitive television-namely, station shortage and restrictive practices.

\section{x. Allocation problems and station scarcity}

Practical telecasting began in the VHF band, but the Commission, as early as x945, recognized the inadequacy of VHF channels, alone, to provide a nationwide competitive system and declared the development of the ultra high frequencies to be essential. ${ }^{22}$ The present-day critical television shortage results from failure to carry out this dictum.

Since 1952, when the Commission promulgated an allocations plan that for the first time included UHF assignments, the number of operating VHF stations has more than trebled, ${ }^{23}$ and two-thirds of the VHF assignments made by the Commission have been taken up. By contrast, I225 of the Commission's I3Ig UHF assignments remain idle, and less than 300 of the 1260 communities to which the Commission assigned one or more channels have a station in operation. Although ${ }_{53}$ UHF stations went on the air, 59 of these failed ${ }^{24}$ and others are in difficulties. Less than 7 million of the 37 million receiving sets in circulation are equipped to receive UHF signals, and the percentage of all-channel sets being manufactured and sold is declining. The problem of spectrum utilization thus remains unsolved, and the fate of UHF broadcasting and of multiple and diverse program sources hangs in precarious balance.

With due allowance for the seniority and greater technical proficiency of VHF broadcasting and for certain differences in the propagation characteristics of the two methods, UHF is inherently capable of performing satisfactory broadcast service. The crux of the UHF problem to date has been the inability of UHF broadcasters to achieve sufficient all-channel set circulation in markets in which, under the allocations plan, they must compete with established VHF outlets. In I952, VHF broadcasting enjoyed a circulation lead of I7 million sets, a lead that has since almost doubled.

Preference of network advertisers for established viewer markets has made it difficult for UHF operators to induce the public to purchase or convert to all-channel sets, because they have been unable to offer superior programming. Conversely, UHF operators have been unable to improve their programming because they lack the set circulation to attract high-budget advertising.

23 See FCC Docket No. 6651, May 25, 1945.

as From ro8 to $36 \mathrm{r}$.

"In contrast, only 4 VHF stations that have gone on the air since July 1952 have ceased operations. 
Although this dilemma was to some extent foreseen by the Commission, its I952 allocations plan, nevertheless, subjected the new technique to unequal competition in areas in which VHF stations were already established. The effect of the error soon became apparent, but the Commission long remained reluctant to consider any real corrective action. In June 1956, the Commission adopted its present orientation toward the allocations problem. This involves a program of research and development testing the feasibility of a major shift of television broadcasting to the UHF band and a market-by-market program of de-intermixture. In February 1957, for the first time, a number of mixed areas were scheduled by the Commission to be turned into all-UHF markets.

The inherent difficulty of correcting the initial allocations error which gave rise to the present UHF crisis has been aggravated by regulatory uncertainty, vacillation, and lack of leadership. The Commission should press its research into the possibilities of a shift to UHF to a speedy conclusion and should utilize the de-intermixture technique to the fullest extent feasible. Congress, in turn, should encourage the production and purchase of all-channel sets by exempting such sets from the federal excise tax. Meanwhile, the Commission must provide leadership in a campaign to educate the public to the recognition that all-channel sets are essential equipment.

\section{Intercity transmission}

Effectiveness of the Commission's regulation of television is also called into question in connection with the Commission's supervision of the intercity transmission of network programs. It has been commission policy that such transmission shall be performed by common carrier, and the bulk of network programming is routed over a system of cables and relays operated by the American Telephone and Telegraph Company and its affiliates.

Because adequate common-carrier facilities are not everywhere available, the Commission has provided by rule for private construction and operation of intercity relay stations, but only on an interim basis until common-carrier service is offered. ${ }^{26}$ Cost of construction, operation, and maintenance of such private relay stations is often substantially less than applicable common-carrier transmission charges. Station operators in remote, sparsely-populated areas contend that common-carrier charges are often disproportionate to the revenue-producing capacities of their stations. Complaining that the Commission's rule places them at the mercy of the telephone company with respect both to the conditions under which private relay facilities may be installed and to the length of time they will be permitted to operate, they have petitioned for a rule change that will permit permanent use of private facilities whenever justified by excessive cost of common-carrier transmission. ${ }^{20}$ This proceeding has been pending since August 1954 without decision.

Meanwhile, a formal investigation of the telephone company's common-carrier

${ }^{25}$ FCC Rules Governing Television Auxiliary Broadcast Stations, 47 C.F.R. $\$ 4.63 \mathrm{I}(\mathrm{c})$ (1956).

${ }^{20}$ FCC Docket No. III64, Sept. I6, I954. 
charges for network transmission services has been pending without determination since April I948. ${ }^{27}$

High common-carrier transmisssion charges and restrictive regulations governing the use of private transmission facilities combine to prevent many rural television stations from obtaining essential network programs for live broadcast. The Commission has recognized that this "may deter and hinder the development of a nationwide television system." ${ }^{28}$ It must speedily bring both proceedings to a conclusion.

\section{II}

\section{fCC Practices in Licensing and Adjudication}

Related, in terms of antitrust significance, to its role of allocating frequencies is the Commission's function of licensing such frequencies to broadcasters. Here the Commission is required to determine whether the public convenience, interest, or necessity will be served by the requested grant. ${ }^{20}$ Since competition is a relevant factor in weighing public interest, the Commission must evaluate the competitive implications inherent in license applications. This requires scrutiny of the transaction underlying the requested license and the antitrust history, if any, of the applicant and its affiliates. It also requires effective cooperation between the Commission and the Department of Justice, which bears ultimate responsibility for antitrust enforcement.

The licensing authority places the Commission in a strategic position to vindicate antitrust principles in television if it remains alert to the importance of curbing monopoly. On the other hand, neglect of competitive factors in licensing and failure of effective liaison between the agencies charged with antitrust responsibility can produce dangerous concentration. The investigation disclosed a number of instances of inadequate interagency liaison and of licensing practices that fell short of protecting the public interest in competition.

In a proceeding initiated before the Commission in I95I, seeking approval of the proposed merger of $\mathrm{ABC}$ and United Paramount Pictures to form American Broadcasting-Paramount Theatres (the present $\mathrm{ABC}$ network organization), failure of liaison was the fault of the Department of Justice. Taking cognizance of the fact that both parties to the proposed merger had been created to remedy restraints of trade, ${ }^{30}$ the Commission held extensive hearings directed, among other things, to determining whether the proposed merger was consistent with an outstanding antitrust consent decree against the predecessor of one of the parties, whether any party had engaged in antitrust violations; and what effect the merger would have

${ }^{27}$ FCC Docket No. 8963 .

${ }^{28}$ FCC notice of proposed rule making, Docket No. III64, Sept. 16, I954.

${ }^{20} 66$ STAT. 714, 47 U.S.C. 3307 (a) (1952).

30 ABC was the transferee of what had been the Blue Network of NBC, which the latter had divested after the Commission in its 1943 chain-broadcasting report found that the operation of two networks by NBC adversely affected competition in the radio industry. United Paramount Theatres, Inc., was organized to take over the theatre properties of Paramount Pictures, Inc., following a consent decree requiring Paramount to divorce its motion-picture operations from its theatre-ownership operations. 
under the antitrust laws. Three months before the hearing began, the Commission called the antitrust implications of the transaction to the attention of the Attorney General and invited Justice Department participation in the hearing. The Department of Justice replied that it would not participate but would like to be heard further if antitrust problems should arise at the hearing. On January 7 , 1953, more than four months after the hearing had closed, and after the hearing examiner had issued an initial decision and the Commisson had heard oral argument, the Attorney General suggested to the Commission that the proposed merger might substantially lessen competition. In these circumstances, the Commission replied that it could not consider matters outside the record, which had been closed after ample opportunity for participation by the Department of Justice. Thereafter, finding that no substantial threat to competition was involved, the Commission approved the merger.

The NBC-Westinghouse exchange of 1955 found the roles of the two agencies as guardians of competition exactly reversed. After notifying the Antitrust Division of the Department of Justice of the pendency of the proceeding and its antitrust significance, the Commission, nevertheless, approved the proposed exchange without a hearing, without waiting for Justice Department comments, and without notice to the Department of its proposed action. A letter from the Department indicating its intention to investigate the transaction came too late to deter the Commission from making its decision public and did not influence the Commission to revoke or reconsider its approval as, under the statute, ${ }^{31}$ it was free to do.

Failure of liaison, here obviously the fault of the Commission, was most unfortunate in this case because-unlike its conduct in the ABC-Paramount merger -the Commission did not regard the antitrust implications of the transaction or the antitrust histories of the parties and their affliates to be of sufficient importance even to warrant a hearing. Briefly, the facts were these: NBC, seeking an owned outlet in the Philadelphia market, persuaded Westinghouse to exchange its valuable Philadelphia stations for those of NBC in Cleveland, plus $\$ 3$ million. Investigation by the Commission's staff gave indication that Westinghouse was most reluctant to part with its lucrative Philadelphia properties and may have been coerced to consent by the risk that it might otherwise lose its valuable NBC affiliations in Philadelphia and elsewhere. Commission staff reports also expressed concern over the concentration of coverage by NBC-owned stations that would result from the exchange. Nevertheless, upon the written assertion of Westinghouse that it had not been coerced, the Commission gave summary approval to the exchange. The Commission's improvidence in this case was in marked and unfavorable contrast with its earlier deliberate scrutiny of the ABC-Paramount merger and also with the subsequent action of the Department of Justice. The Department, commendably, completed its investigation and filed an antitrust suit. ${ }^{22}$

\footnotetext{
${ }^{31} 66$ STAT. 715, 47 U.S.C. $\$ 309$ (c) (1952), and 48 STAT. 1094 (1934), 47 U.S.C. $\$ 403$ (1952).

${ }^{89}$ Civil No. 21743, E.D. Pa., filed December 4, 1956. The complaint alleges that the Radio Corporation of America and its subsidiary, NBC, have violated $\S$ I of the Sherman Act (50 Stat. 693 (1937), I5 U.S.C. $\$$ I (1952)) by conspiring to obtain VHF television ownership in 5 of the 8 largest
} 
To this comment on the NBC-Westinghouse case, where the Department of Justice and the Federal Communications Commission acted at cross purposes, with scant attention given by the latter to antitrust considerations, must be added a note of concern with respect to the informality which has characterized the Commission's adjudicative function in this and other cases. For at least the past ten years, this informality has been such that Commission members have repeatedly discussed the merits of pending cases with parties. That such ex parte discussion of contested issues is inconsistent with adjudication is a proposition too clear to require argument.

These aspects of the Commission's licensing and adjudicative practices constitute a soft spot in federal regulation that must be removed. There is need for the adoption of a code of ethics that will provide a positive guide to permissible and impermissible behavior and for the appointment of personnel aware of and devoted to the public interest.

\section{III}

\section{The Television Networks}

Networking is so uniquely the heart and core of present-day television that any appraisal of the industry-or of restrictive practices obstructing its full development -must take into account the origins, affliations and character of the network organizations. Each of the three operating networks, CBS, NBC, and ABC had its origin in radio. ${ }^{33}$ Each was and is an integral part of an enterprise whose activities transcend radio and television broadcasting. The central role played by all three existing chains and the dominance of the television industry enjoyed by CBS and NBC are attributable in some measure to these factors

The CBS television network is a division of the Columbia Broadcasting System, which was organized in 1927. The company is a leading producer of phonograph records and electronic equipment. It recently discontinued the manufacture of radio and television receiving sets.

NBC, organized in 1926 , is a wholly-owned subsidiary of Radio Corporation of America, a vast electronics enterprise and leading manufacturer of radio, television, and motion-picture equipment of all kinds. RCA controls about ro,00o patents covering equipment used in connection with broadcasting ${ }^{34}$ and operates a worldwide radio-telegraph communications system. Until 1943, NBC operated two radio

American markets, through unlawful use of NBC's power to grant or withhold network affiliation. On January 10, 1958, the District Court held, among other things, that the FCC had primary jurisdiction over the Philadelphia-Cleveland transfer and that the transaction was not subject to collateral attack by the Department of Justice. See, also, Hansen, Broadcasting and the Antitrust Laus, elsewhere in this symposium.

${ }^{38}$ An investigation of I938-4I, which culminated in FCC, REPORT on Chain Broadcasting (194I), disclosed that CBS and NBC were accounting for more than one-half the revenue of the entire radio broadcasting industry and that $85 \%$ of the nation's night-time broadcasting power was available exclusively to these networks, which owned many of the most desirable stations.

"The complaint in a pending antitrust suit filed on November 19, 1954 (United States v. Radio Corporation of America, Civil No. 97-38, S.D.N.Y.), charges RCA with monopolization of the radio-television patent licensing business. RCA denies the charges. 
networks. In that year, after a finding of the Federal Communications Commission that such operation was not in the public interest, NBC divested its Blue Network, retaining the Red.

$A B C$ was originally the Blue (radio) Network, divested by NBC. In 1948, it began operating a television network, and in 1953, it merged with United Paramount Theatres, which had, in turn, been formed in consequence of the divestiture of theatre-owning operations by Paramount Pictures, in compliance with an antitrust consent decree. The resultant American Broadcasting-Paramount Theatres operates 605 theatres and has recently announced its intention of producing motion-picture films through a subsidiary. It also manufactures phonograph records.

In addition to the foregoing diverse activities, each organization operates a radio network and a television network, owns and operates radio and television stations in key market areas, and engages in the production of radio and television programs, the latter both live and on film.

For 1955, the CBS and NBC television networks and the nine stations then owned by them together reported broadcast revenues of $\$ 312,658,470$, comprising $4^{\mathrm{x}} .99$ per cent of the business done by the entire television broadcasting industry, and enjoyed broadcast income before taxes of $\$ 65,050,186$, representing 43.4 per cent of the entire industry's broadcast income. $A B C$ and its five stations had broadcast revenues of $\$ 53,906,480$, or 7.24 per cent of the industry total, and broadcast income of $\$ 5,589,452$, or 3.7 per cent of the industry total.

The following tabulation highlights the position of the network organizations in the industry as of the end of 1955 . It shows the extent of their affiliations and their strategic occupation of key markets with network-owned stations for both radio and television. Further, with respect to television, it gives the percentage of the public reached by network-owned stations, the profitability of network and networkowned station operations, the revenue and profit positions of the networks and their owned stations relative to the entire industry, and the proportion of all station profits enjoyed by network-owned stations:

Position of the Networks

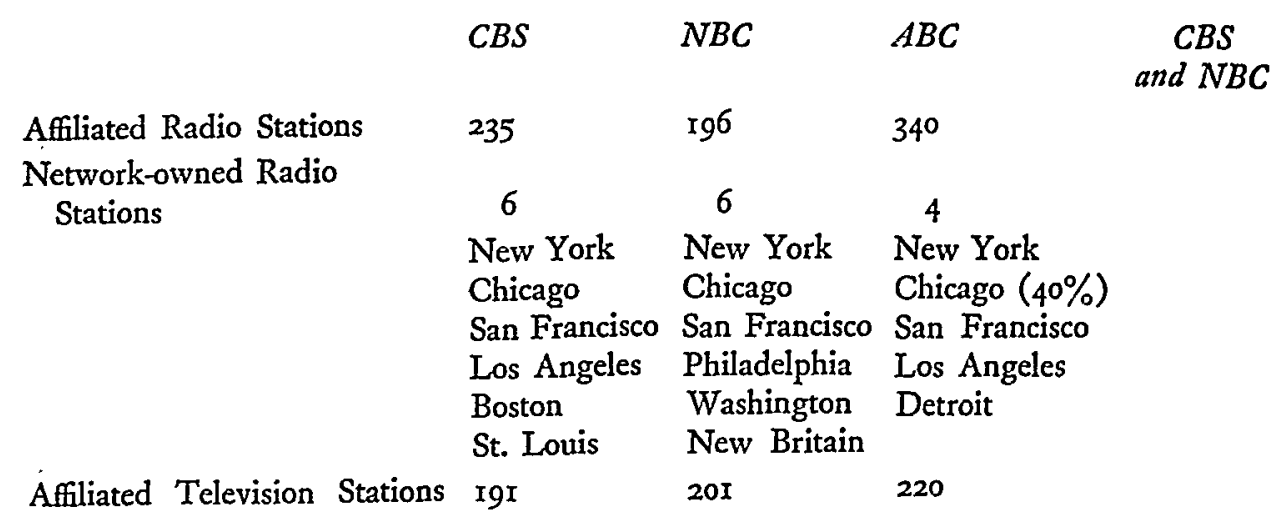


Network-owned Television

Stations

6

VHF: New York

Chicago

Los Angeles

St. Louis

UHF: Milwaukee

Hartford

Percentage of U.S. population reached by network-owned television stations

Ratio of $x 955$ profit to $\mathrm{x} 2 / 3 \mathrm{I} / 54$ investment in tangible property (networks plus owned TV stations)

Percentage of total TV industry revenue for 1955 (network plus owned TV stations)

Percentage of total TV industry income before tax, 1955 (network plus owned TV stations)

Percentage of all station profits, 1955, enjoyed by network-owned stations

\subsection{3}

24

1.29

23.3

I2.5
7

New York

Chicago

Los Angeles

Philadelphia

Washington

Buffalo

New Britain

27

I.33

.85

I.3T

New York

Chicago

Los Angeles

San Francisco

Detroit

I.3

$2 \pi .96$

7.24

41.99

20.1

$3 \cdot 7$

$43 \cdot 4$

25.9
I3.4

$4 \cdot 4$

The dominance of CBS and NBC in television, which the table illustrates, flows: in part from their historical dominance in radio, in part from faulty allocations of television frequencies by the Federal Communications Commission, and in no small part from the programming which these networks, as well as $\mathrm{ABC}_{9}{ }^{35}$ have brought to the public. The networks have, at considerable financial outlay and risk, pioneered in developing the great new medium of television, producing on a simultaneous. nationwide basis public service, cultural, and entertainment programs of national interest. Certain restrictive practices have also, however, contributed to concentration in the industry by giving the networks inordinate control of the broadcast time of their affiliated stations. These practices must be corrected if television is toachieve its full competitive promise. Congress intended to authorize a communications system in which local and regional self-expression would be encouraged by the

${ }^{35}$ The writcr believes that the failure of $A B C$ to achieve full parity with the two dominant networks is attributable to three factors. First, it was a late-comer, originating as the less profitable of NBC's two radio chains. Second, when established $\mathrm{CBS}$ and NBC radio affiliates turned to television, they were not only successful contenders for VHF licenses, but they naturally contracted television affliations with the organizations with which they were already allied in radio. As a consequence, and most important, $A B C$ has had to eke out its market coverage to a greater degree than CBS or NBC by using UHF stations. in intermixed areas where they do not command the fullest viewer or advertiser acceptance. 
establishment of multiple, diverse, and independent program sources. It did not contemplate a situation in which the prerogatives of program selection would be so highly concentrated.

\section{IV}

\section{Practices Susceptible of FCC Regulation}

A number of restrictive practices arise out of the relations between the networks and their affiliated stations and have been or could be made the subject of supervision by the Commission in radio as well as television, under its chain-broadcasting regulations, first promulgated in r94I and formally applied to television in 1945. These regulations, designed to remedy competitive abuses disclosed by a three-year investigation, forbid licensing of any station whose relations with a network violate specified principles.

Under the chain-broadcasting regulations, no station may agree to refrain from affiliating with a different network and no network may agree to withhold its programs from a different station in the area after such programs have been rejected by the affiliate. Permissible duration of affiliation agreements is limited to two years. Option time arrangements, by which a station agrees, as a condition of affiliation, to carry network-sponsored commercial programs during "network option time," are limited to not more than three hours in each of four specified segments of the broadcast day, ${ }^{36}$ and no contractual provision may prevent a station from rejecting a program reasonably believed by it to be unsatisfactory, unsuitable, or contrary to the public interest, or may prevent substitution of a program of outstanding national or local importance.

As originally formulated, the chain-broadcasting regulations provided special limitation on the number of station licenses a network organization could obtain in a single area. Subsequently, the Commission adopted multiple-station ownership rules in both radio and television, which apply to all licensees, irrespective of their character as networks. The present rule in television permits ownership of seven stations, not more than five of which may be VHF.

A regulation prohibiting the operation of more than one radio network simultaneously and in overlapping territories was suspended when it appeared that NBC would separate the ownership of its Red and Blue networks without need of a rule. Finally, the regulations forbid agreements permitting a network to fix a station's time rate for nonnetwork programs.

In order to assure that provisions of the chain-broadcasting regulations are not violated, copies of all network affiliation agreements are required to be filed with the Commission, which examines them for conformity with the regulations. The Commission does not, however, study the agreements to evaluate differences in their terms or to determine whether such differences are in the public interest. Nor does it make them public.

${ }^{80} 8$ A.M. to I P.M.; I P.M. to 6 P.M.; 6 P.M. to II P.M.; and II P.M. to 8 A.M 
In context of current proposals to eliminate or relax one or more of the existing limitations on television network practices and proposals to impose new and sharper limitations, the effect of a number of these practices upon competition in the television broadcasting industry merits examination here. This is particularly true of network ownership of stations, the "must buy" requirement on advertisers, option time, and the "first call" rule.

As has been shown, the networks have used the existing multiple station ownership rule ${ }^{\mathbf{3 7}}$ to buttress their dominance of television by the ownership and operation of broadcasting stations in key areas of the nation. ${ }^{38}$ Multiple ownership of broadcasting stations by a single interest, irrespective of its character as a network, leads to concentration, militates against the national objective of diversity of program sources, and lends itself to anticompetitive abuses. Network affiliation agreements examined by the Antitrust Subcommittee reveal that multiple-station owners often derive substantial advantages over sole-station owners in compensation and other terms, making it difficult for sole-station owners to compete effectively with owners of several stations.

A further possible abuse is facilitated when the multiple-station owner is a network. Common ownership of network and station places the network in a position where, in dealing with advertisers, its proprietary interest may conflict with its interest as the representative of affiliated stations. The danger arises that it may favor its owned stations at the expense of its affiliates.

These and similar objections to the widespread multiple ownership of broadcasting stations have been voiced by the head of the Antitrust Division of the Department of Justice, ${ }^{39}$ the Director of the FCC Network Study Group, ${ }^{40}$ and the Commission itself. ${ }^{41}$ The multiple-ownership rule should, if anything, be rendered more stringent; it should not be relaxed.

As a condition of the sale of network time, all three networks currently require the advertiser to purchase the time of a specified group of affiliated stations. For each chain, this "must buy" requirement embraces all network-owned stations. To round out the basic required group, CBS adds $5 \mathrm{I}$ and $\mathrm{NBC}$ adds $5^{\circ}$ other affiliates. The minimum aggregate evening hourly time charge of these networks exceeds $\$ 70,000 .^{42}$

$\mathrm{ABC}$ requires the purchase of time on no specified stations other than those

${ }^{37}$ The present rule permitting ownership of 7 television stations, not more than 5 of which are VHF, was adopted in 1954 to encourage UHF broadcasting by multiple-station licensees.

${ }^{8 B}$ See table, supra pp. 558-59.

${ }^{\text {aD }}$ Hearings, supra note 3 , vol. 2 , at 4122-23.

${ }^{\circ} \mathrm{Id}$., vol. $\mathrm{I}$, at $376 \mathrm{r}$.

${ }^{41}$ FCC, op. cit. supra note 33, at 67; Hearings, supra note 3, vol. I, at 3603. Also see FCC, IN THE Matter of. Amending the Rules and Regulations Relating to AM, FM, and Television Broadcast STATTONS (r953).

${ }^{4}$ Network time charges for each affiliated station are fixed by the networks on the basis of such factors as the station's receiving set circulation in its unduplicated coverage area. The charge for an evening hour may range from $\$ 150$ for a station in a small community to $\$ 7500$ for a station in New York City. 
owned by it, but the advertiser must select additional stations in sufficient number to yield the network minimum time charges of $\$ 50,000$ for an evening hour.

Legality of the "must buy" requirement under the antitrust laws is in sharp dispute. The Department of Justice has asserted that, in its tendency to coerce advertisers to the purchase of time on stations they do not want, the requirement may constitute a per se violation of the Sherman Act, and that it may also unduly restrict unaffiliated stations in selling time to network advertisers. ${ }^{43}$ CBS and NBC, on the other hand, assert that "must buy" is a minimum requirement reasonably zelated to the needs of the national advertiser. They regard it as facilitating the assembly and sale of an indivisible product, and hence as involving no tie-in. ABC defends its "must buy" requirement as designed to help meet the cost of a balanced program structure.

Irrespective of the legality or illegality of "must buy" under the antitrust laws, its present rigidity can and should be relaxed in the interest of advertiser freedom of choice as well as the interest of unaffiliated stations attempting to compete with network affiliates. The leverage of the requirement, particularly as imposed by CBS and NBC, to force an advertiser to accept television coverage that he does not want in order to get coverage he needs is obvious. It may account for the fact that only the largest advertisers are willing to use network television as a commercial medium, as evidenced by the fact that approximately one-half the dollar volume of all network time sales is accounted for by about 25 advertisers. ${ }^{44}$ Equally apparent is the impact of this requirement on a station desired by the advertiser, but not included in the network's "must buy" list, in shutting it off from business it would otherwise receive.

Of course, the networks must not be fragmented. This would be avoided by adoption of a Federal Communications Commission rule, under its licensing authority, prohibiting the requirement of the purchase of time on designated stations, but permitting imposition of a minimum time charge, to be fixed by the networks at a figure high enough to hold the network together but not so high as to deprive the advertiser of real flexibility in station selection.

The networks are enabled to enforce "must buy" requirements largely because they control segments of the most desirable broadcast hours of their affiliates by means of option-time arrangements in affliation agreements, which provide that the station will, on $5^{6}$ days' notice, broadcast all commercial programs offered by the network. This provision is qualified by the reservation that the station may refuse any program which it reasonably believes to be unsatisfactory, unsuitable, or contrary to the public interest and may substitute for a network program a program of outstanding local or national importance. Further, the option-time provision may not be used to oust the program of another network. ${ }^{45}$

${ }^{48}$ See Hearings, supra note 3 , vol. 2, at 4r30-40.

"Id. vol. $\mathrm{I}$, at 3525 .

${ }^{45}$ As so restricted, and limited to not more than 3 hours in each of 4 segments of the broadcast day, time options are permitted by the chain-broadcasting regulations. See note 36 sipra. 
The history of these provisions is instructive. In its Report on Chain Broadcasting of 194I, the Commission proposed to abolish time options, stating that they "have restricted the freedom of station licensees and hampered their efforts to broadcast local commercial programs, the programs of other national networks, and national spot transcriptions," that "these considerations far outweigh any supposed advantages from stability of network operations under time options," and that "the optioning of time by licensee stations has operated against the public interest." ${ }^{36}$ CBS and NBC protested that the optioning of time was indispensable to network operations. After rehearing, the Commission, rejecting this contention of the networks, proposed an amended rule which prohibited a time option from being exclusive as against the program of another network organization, but permitted time optioning of not more than three hours in each of four segments of the day. This amended rule ultimately became effective over the strenuous protests of the networks that unavailability of an option to oust the program of another network would make it virtually impossible to clear time for national radio and television programs.

In spite of these dire predictions, the networks have prospered under the operation of the rule. Similar contentions are now made by the networks with respect to proposals to eliminate or curtail option time. In the light of past developments, these predictions must be viewed with skepticism. Moreover, if, as the networks suggest, their survival depends upon curtailment of competition, comprehensive utilitytype regulation would be necessary in order to safeguard the public interest. Such an expedient should not be resorted to except as a last resort. It is certainly not justified under present conditions.

That option-time provisions do tend to curtail competition cannot be doubted. First, they tend to substitute the network's programming decisions for those of the station licensee. Second, they tend to enable the networks to bar the programs of competing producers from access to station outlets during important broadcast hours. Third, they tend to prevent nonnetwork advertisers from competing effectively with network advertisers for prime station time. Fourth, they tend to deprive the public of that full choice of programs that would be available in a free competitive market. There is a marked similarity between time-optioning and block-booking in the motion-picture industry which the Supreme Court has proscribed as contrary to the antitrust laws. ${ }^{47}$ Indeed, it has been pointed out that time optioning is

an even more virulent practice than block booking for not only does it commit the station in advance to take a whole block of programming, but it is a combination or arrangement between the networks and their affiliates to oust the programs of important competitors in order to honor the option. 48

"FCC, op. cit. supra note 33 .

"Tee United States v. Paramount Pictures, Inc., 334 U.S. 131, 156 (1948), where the Supreme Court described bloc-booking as "the practice of licensing, or offering for licensing one feature or group of features on condition that the exhibitor will also license another feature or group of features released by the distributors during a given period. The films are licensed in blocks before they are actually produced."

${ }^{48}$ Memorandum prepared by special counsel, Senate Committee on Interstate and Foreign Commerce, 
Abandonment of time options would not prevent a network from contracting in advance for station clearance. It would merely restore to the station its freedom to accept or refuse the program on its merits. In this connection, the reservations under which a station may now reject a program are not much protection to it. The networks have terminated the affiliation of stations who have carried too few network programs, and a network affiliation is essential to station prosperity.

The writer believes that abolition of time options would work a salutary restoration of free competition in television programming, without materially hindering the networks in obtaining clearance for network programs of quality.

The purpose of the chain-broadcasting regulation which prohibits territorial exclusivity of network programs is to assure that an affiliated station will not be able contractually to restrict the broadcast by other local stations of network programs which the affiliate decides not to carry. The "first call" rule modifies this regulation by sanctioning agreements by which a network undertakes to offer its affiliate the right of first refusal of all programs for broadcast locally. Abuse of this privilege, however, may be present when the affiliate exercises its right of "first call" to make delayed broadcast of a network program at hours at which few persons watch television or when the program is no longer timely. Such practice contravenes the clear purpose of the rule, enabling the affliate, in effect, to suppress the program locally rather than to permit its broadcast by a competitor. The adverse effects of such a practice are clear. It increases the competitive advantage of the affiliated station over others, aggravates the survival problem of UHF stations by restricting their program sources, and deprives the local public of desirable network programs.

The Commission could minimize these effects by imposing limitations upon the conditions under which the "first call" privilege may be used to delay the broadcast of television network programs. Factors relevant to such a limitation are: the nature of the program substituted for the delayed program, whether local or network; the relative desirability of the period in which the delayed program was originally scheduled and the period in which it is later broadcast; and the length of the delay. In light of evidence of network objection to the use of network-owned programs in "building up" competition to network-owned stations, ${ }^{40}$ the Commission should also consider requiring the networks, when their program is not broadcast by the local affiliate, to give notice of program availability so that other local stations may have opportunity to carry the program.

Effective regulation of network practices by the Federal Communications Commission would be materially aided if the Commission currently studied the terms of the affliation agreements required to be filed with it not only for conformance with the chain broadcasting regulations, but also for consistency with the public interest. Examination of current affliation agreements by the Antitrust Subcommittee, for

Television Network Regulation and the UHF Problem, 84th Cong., Ist Sess. 33 (1955). Also sec Staff Report, Senate Committee on Interstate and Foreign Commerce, Television Network Practices, 85 th Cong., Ist Sess. 8-64, 97 et seq. (I957).

${ }^{4} \mathrm{See}$, e.g., Hearings, stupra note 3 , vol. 4, at 5682. 
example, revealed the existence of widespread and arbitrary differences in the terms accorded by each network to its individual affliates in respect of compensation for network broadcasting services. Moreover, these differences mainly favored larger, multiple-station licensees over small independent operators. Such discrimination, when based primarily on considerations of financial stature, can only lead to increased concentration.

The Commission should consider the advisability of opening to public inspection all affiliation agreements on file with it..$^{50}$ Such a step might not only reduce the present inequality of bargaining power between the networks, with their total knowledge of the terms of all their agreements, and the small, individual licensee who must bargain on the basis of only such knowledge as he can pick up, but would also subject network affiliation practices to the test of public scrutiny. With all respect for the interest of the networks in maintaining the privacy of their business arrangements, it is far from clear to this writer that the sanctity of this privilege of privacy outweighs the interest of the public in knowing the manner in which resources licensed in its behalf are being exploited. In any event, the Commission should adopt the policy of studying and learning from the filed agreements, in aid of its regulatory duties.

\section{$\mathrm{V}$}

Network Programming Practices and Talent Contracts

By exercising final responsibility for network program content, the networks reserve to themselves great power to determine what shall be seen and heard on television. Through the use of time options, they pre-empt the most desirable broadcast hours of all but a few stations to the use of network advertisers.

In addition, the networks have extensively entered the business of program production. ${ }^{51}$ This means that they must often exercise a choice between programs in which they have a direct financial interest and those offered by independent competing producers. Here, as in the case of network ownership of broadcasting stations, there is danger of a conflict of interests. The interest of the network in providing the best obtainable programming may conflict with its interest in the broadcasting of programs in which it has a financial stake. Independent producers have contended that when a network and an independent producer both seek to sell an advertiser for the same time period, the network is prone to disapprove the independent's production on grounds related to "good programming" or "the public interest." In light of the networks' explanations of instances offered, the Antitrust Subcommittee reached no conclusion as to whether the networks do tie sales of network time to the sale of programs in which they are financially interested. Nevertheless, the danger inherent in these relationships and interest alignments is obvious.

${ }^{\circ} \mathrm{See}$, in this connection, Senate Committee on Interstate and Foreign Commerce, supra note 48 , at 95.

81 For selected recent periods, the percentage of programs in which each network had a financial interest, compared to the total number of programs broadcast by it, was as follows: CBS, 50.5; NBC, 46.9; $\mathrm{ABC}, 27.8$. 
Moreover, in dealing with independent producers of television programs, the networks tend to demand more than the mere right to broadcast. They also demand, and their strategic bargaining position often enables them to achieve, the right to participate in the prospective profits from any rerun of the program after its initial broadcast, and from so-called subsidiary rights. ${ }^{52}$ The potential anticompetitive consequences of these demands for profit participation in independently produced programs are threefold: access of independently-produced programs to the national networks tends to become subject to the payment of toll; network-owned programs tend to receive an artificial trade advantage over programs owned by others; and advertisers tend to be restricted in their choice of programs, in so far as they lose access to those of independent producers.

Here, again, the practices of the networks in program production are highly suggestive of the conditions condemned in the Supreme Court in the Paramount Pictures case $^{53}$ where motion-picture producers, through strategic control of theatres, secured great competitive advantage over rival film producers, and divorcement of the defendants' production operations from their theatre operations was ordered. ${ }^{54}$

As part of their programming activities, the networks also keep a substantial number of performers of various types under long-term exclusive contracts. The duration and exclusive character of these contracts tend to restrict from access to outstanding talent not only competitors of the networks in the radio and television industry, but also noncompetitive enterprises like night clubs and theatres. Moreover, some of the agreements impose restrictions on the performance of the artist outside the geographic limits within which the network operates.

In addition, NBC engages in artist-management practices of a type that was one of the subjects of complaint in the antitrust case of United States v. Radio Corporation of America, ${ }^{55}$ as the result of which NBC and CBS sold all their interests in artists and concert bureaus. Under such present arrangements, the network is given the right to direct the artist's activities and to retain all proceeds from performances other than on television. Such practices, if permitted to grow, can have lasting ill effects on the talent-management business.

The Antitrust Division of the Department of Justice has advised that it is engaged in a broad-gauge investigation of network operations to determine whether antitrust suits should be instituted. The practices of the networks with respect to television programming and talent contracts provide a fertile field for the Division's scrutiny.

\section{VI}

\section{Broadcaster Activitres in Music}

The history of the radio and television industry has been marked by a continuing

"s Subsidiary rights involve exploitation of the popularity of the program by licensing the use of its name or the name or likeness of one or more members of its cast to manufacturers and distributors of commercial products. Profit participations range from 25 to $50 \%$.

${ }^{6}$ United States v. Paramount Pictures, Inc., 334 U.S. I3x (r948).

"United States v. Paramount Pictures, Inc., 85 F. Supp. 88x (S.D.N.Y. 1949).

${ }^{55}$ Civil No. 3763 , N.D. Ill., 1941 . 
struggle between songwriters and broadcasters over royalties to be paid for the public performance of copyrighted music. This conflict, which in 1939 impelled the broadcasters to enter the music-licensing business in their own behalf, has given rise to institutional practices carrying grave antitrust implications.

For 25 years after its organization in 1914, the American Society of Composers, Authors and Publishers (ASCAP), an unincorporated performing-rights society, enjoyed a virtual monopoly in the business of licensing the performance of music for profit. Composed of approximately 4,000 songwriter-members and 875 music publisher-members and managed by a board on which the two groups have equal representation, ASCAP licenses the performance of its members' music, collects royalties, and distributes the net proceeds to its members. Participation in royalty distributions and in the election of directors is proportioned to the frequency with which a member's music is performed.

Under a five-year nationwide contract expiring December 3r, I940, ASCAP was receiving from individual broadcasting stations as royalties for the performance of ASCAP-licensed music a specified percentage of each station's receipts from both network and nonnetwork programs. In renewal negotiations, ASCAP sought to hold the networks responsible for royalties on network programs at a higher rate. This proposal was firmly resisted by the broadcasters.

For the purpose of acquiring a bargaining weapon for use against ASCAP, whose members then included almost all the established songwriters, the broadcasting industry, in 1940, organized Broadcast Music, Inc. (BMI), its own music-licensing organization. Stock ownership in BMI is limited to broadcasters. ${ }^{56}$ On behalf of its broadcaster-owners, BMI acquires licenses for the public performance of music and, in turn, licenses such performance to broadcasters and others. BMI pays no dividends. It grants licenses under contracts providing maximum royalty rates, from which broadcasters, but not nonbroadcaster licensees, are then allowed a pro rata discount, called a "rebate," in the amount by which total BMI costs fall short of such contract maxima. ${ }^{57}$ Broadcasters thus receive their licenses at cost to BMI, as reduced by any profit realized by BMI from licensing nonbroadcast performance.

The 1940 negotiations between the broadcasters and ASCAP resulted in a memorable impasse. From November I, I940 until November I, I94I, when the dispute was finally settled, virtually no ASCAP-licensed music was heard on the air. BMI had been in existence too short a time to have developed a substantial repertoire, with the consequence that the broadcasters and the public had to make do with compositions that had come into the public domain. The bulk of popular music, during this period, was simply blacked out.

Early in 194I, during the blackout, antitrust suits were instituted against both

${ }^{48}$ The networks are the largest shareholders of BMI, owning an aggregate of $25.6 \%$ of its stock. In addition, CBS and NBC together underwrote an $\$ 800$, 00o obligation of BMI, constituting the unpaid balance of the purchase price of the music catalogue of a large music publishing concern.

${ }^{67}$ Such rebates to broadcasters bear no relation to the amount of stock owned in BMI. 
ASCAP and BMI, and both suits culminated in consent decrees.58 In part, no doubt, because ASCAP had been in existence for many years, ${ }^{50}$ whereas BMI was then less than two years old, the decree against ASCAP has a much more severe impact upon the songwriter-broadcaster conflict than that against BMI. Thus, where the decree against BMI is directed essentially against discrimination by BMI in the licensing of music to users, the decree against ASCAP, as modified in 1950, directly affects ASCAP's practices vis-à-vis broadcasters and other licensees in the following respects: (I) ASCAP must make available to broadcasters a per-program license in addition to the familiar blanket license; (2) ASCAP's license for network programs and motion-picture films used in theatres must run to the network or the motion-picture producer, and not to the individual station or theatre; and (3) any user of music may apply to the court for a determination of rates whenever the user feels dissatisfied with the rate quoted by ASCAP. ${ }^{80}$

BMI has been vigorous in urging the broadcasting community to patronize BMIlicensed songs. It has engaged in extensive exhortation, both orally and by means of mimeographed and printed publications, reminding broadcasters that BMI music is "their" music and urging them to increase their broadcasting of such music in proportion to ASCAP music. In this, BMI has perhaps stressed the self-interest of the broadcasters more heavily than the quality of the compositions involved. Further, as a goodwill device, BMI has engaged in a variety of free services to broadcasters.

Songwriters contend that, in addition, BMT has engaged in unethical inducements, e.g., of ASCAP writers to conceal their authorship of compositions in order to permit their inclusion in the BMI repertoire; of ASCAP publishers to transfer compositions to BMI publishers in violation of the ASCAP membership agreement; of ASCAP writer-members to resign and become affliated with BMI. Similarly, they complain that BMI subsidizes publishing firms, performers, disc jockeys, and record companies in the interest of exploitation of BMI music. They assert that these alleged practices have contributed to a situation in which broadcasters are sharply discriminating against ASCAP music and favoring music licensed by their own licensing agency, for reasons unrelated to the intrinsic merit of the compositions involved.

Although the relative performance of ASCAP and BMI music has varied over the years, ASCAP continues to predominate over BMI in performance of songs in the important category known as "popular." To this, songwriters reply that the num-

\footnotetext{
${ }^{68}$ United States v. American Society of Composers, Authors and Publishers, Civil No. 13-95, S.D.N.Y. r94I; United States v. Broadcast Music, Inc., Civil No. 459, E.D. Wis. 1941.

${ }^{\circ}$ An antitrust suit instituted against ASCAP in 1934, but never tried, was discontinued without prejudice at the time of entry of the consent decree. United States v. American Society of Composers, Authors and Publishers, Eq. No. 78-388, S.D.N.Y. I934-

${ }^{60}$ The decree also limits ASCAP to the licensing of nondramatic performing rights in musical compositions; prescribes conditions of membership, management, and distribution of royalties; and provides for arbitration of the claim of any member who is dissatisfied with his apportionment of royalties.

${ }^{\text {ex }}$ Music is classified as country and western, or folk; rhythm and blues; Latin American; classical or serious; and popular. BMI is dominant in the first and second, and has been dominant in the third of these categories. In terms of frequency of public performance, popular music is the most important.
} 
ber of BMI "hits" in recent years is disproportionate to the total number of performances of BMI songs as compared to ASCAP songs. They argue that ASCAP over-all predominance may result exclusively from the broadcast of old ASCAP favorites whose publication antedates BMI and that the performance of new songs (of which hits are made) may reflect sharp discrimination against ASCAP compositions. Statistics under the proposed breakdown are not, however, available. The writer does not evaluate these arguments.

There is a clear public interest in access of the best music to the airwaves. The experience of 1940-4I, when popular music went substantially unheard, illustrates the power of the broadcasters, even then, to deny that access to ASCAP music. That power is immeasurably greater today by virtue of the existence of a substantial repertoire of songs licensed to BMI. Finally, as BMI has stoutly maintained, an incentive exists for broadcasters to exploit music licensed by their own agency. In the circumstances, it is imperative that the Antitrust Division of the Department of Justice most searchingly scrutinize the exploitation of music in the broadcasting field to determine whether antitrust suit should be instituted.

\section{VII}

\section{Discounts in the Sale of Network Trme}

Whether the present practice of each network in fixing the network time rate of its affliated stations constitutes illegal price fixing under the antitrust laws is a question now under consideration by the Antitrust Division of the Department of Justice. ${ }^{22}$ In addition, each network allows advertisers a variety of quantity discounts which run as high as 25 per cent and which are not related to any cost saving. Such discriminatory discounts in the sale of goods might well constitute violations of the Robinson-Patman Act. ${ }^{63}$ In as much, however, as that Act is apparently not applicable to the sale of services, ${ }^{84}$ the large network-advertiser is able to obtain a competitive advantage solely by virtue of his superior mass purchasing ability. This is true although there is no. distinction in principle between discrimination in the sale of goods and discrimination in the sale of services. Similarly, section three of the Clayton $\mathrm{Act}^{65}$ which bans certain tie-in arrangements, is not applicable where

\footnotetext{
${ }^{09}$ In antitrust suits filed against $C B S$ and NBC in $194 \mathrm{I}$, it was alleged that a similar practice in radio broadcasting violated the Sherman Act.

${ }^{82} 49$ STAT. 1526 (1936), 15 U.S.C. \$13 (1952).

${ }^{04}$ Cf. Times-Picayune Publishing Co. v. United States, 345 U.S. 594, 610 D. 27 (1953). In that case, the Supreme Court reserved the question whether advertising space in a newspaper is a "commodity" within the meaning of $\$ 2$ of the Robinson-Patman amendment. See also Syracuse Broadcasting Corp. v. Newhouse, 236 F.2d 522, 527 (2d Cir. 1956). In 1937, the Federal Trade Commission ruled informally that advertising space in a magazine was not a commodity within the meaning of $\$ 2(a) .8 x$ Cong. Rec. 2336 (1937). See also Fleetway, Inc. v. Public Service Co., 72 F.2d 76I (3d Cir. 1934), holding that "commodities" as used in $\$ 2$ of the Clayton Act did not include rates of transportation of passengers by bus. $C f$. McKinley Telephone $C_{0}$. v. Cumberland Telephone Co., 152 Wis. 359, 140 N.W. 38 (1913), holding that the supplying of telephone service is the supplying of a "commodity of commerce."

${ }^{\text {OE }} 38$ STAT. 73I (1914), 15 U.S.C. \$ 14 (1952).
} 
services are involved. ${ }^{66}$ To close these loopholes in existing law, the writer has introduced a bill in Congress to amend the relevant sections of the Robinson-Patman Act and the Clayton Act so as to make them applicable not only to the sale of commodities, but also to the sale of services by an independent contractor. ${ }^{67}$

\section{VIII}

\section{Conclusions}

Commercial television broadcasting is today a basically healthy, competitive industry, still largely in its infancy and capable of duplicating its past rapid growth. The task of keeping the industry healthy and competitive-of avoiding both the Scylla of uncontrolled concentration and the Charybdis of overprotection-presents a vital challenge to federal regulatory policy.

In the opinion of this writer, the existing legislative scheme provides ample authority for regulation of the television broadcasting industry in the public interest, which includes national antitrust principles. ${ }^{68}$ What is needed is not more laws, but more vigilant administration of existing law. To this end, the Federal Communications Commission must redouble its efforts to solve the allocations problem, it must revise its licensing practices and policies to give greater weight to competitive considerations, and it must more closely conform its adjudicative practices to the dictates of due process of law.

In rule-making and in enforcement, close attention must be given to industry practices which tend to restrain competition. Those practices which involve networks or broadcasters in potential conflicts of interest, such as network ownership of broadcasting stations, network engagement in program production, and broadcaster activities in the licensing of music, are particularly susceptible of anticompetitive abuse. Existing rules in this area must, in general, be strengthened, not relaxed. One step in this direction is taken by the Network Study Group's recent recommendations that multiple ownership-both by networks and others-be limited, that network affliation agreements be opened to public inspection, and that "must buy" and option-time restrictions be prohibited. ${ }^{69}$

The Antitrust Division of the Department of Justice should bring its pending investigation to a prompt conclusion, to be followed by suit if indicated. Finally, both the licensing process of the Commission and the enforcement function of the Antitrust Division should be strengthened by the improvement of liaison between the two agencies.

${ }^{\circ 0}$ See United States v. Investors Diversified Services, 102 F. Supp. 645 (D. Minn. 1951).

${ }^{o 7}$ H.R. 8277, 85th Cong., Ist Sess. (r957).

${ }^{\circ}$ This observation does not apply to present proposals to experiment broadly in the techniques of subscription television. The Communications Act does not clearly envisage television for a price. Moreover, subscription television involves such basic departures from existing practice and contains such a grave potential threat to the survival of traditional "free" television, that the decision whether or not to embark on these widespread tests should be made by Congress and not by the Federal Communications Commission.

${ }^{69}$ See FCC, op. cit. supra note 17. 
All the measures which have been suggested are essential to the continued growth of healthy, competitive television. All are within the competence of existing regulatory and enforcement agencies. Only if the agencies fail to carry out their responsibilities will appropriate legislative proposals have to be considered by Congress.

The American people have a vital stake in the realization of a truly nationwide and competitive television system. They must not be disappointed. 